\title{
Red Squirrel (Tamiasciurus hudsonicus) Midden Site Selection and Conifer Species Composition
}

\author{
Eric K Elkins \\ Dept. of Animal and Range Sciences, Montana State University \\ PO Box 172900, Bozeman, MT 59717-2900, USA \\ Tel: 1-406-994-5558 E-mail: eelkins14@ hotmail.com \\ Daniel B Tyers \\ United States Department of Agriculture Forest Service \\ Interagency Grizzly Bear Study Team, 2327 University Way, Bozeman, MT 59718, USA \\ Tel: 1-406-994-2281Ｅ-mail: dtyers@fs.fed.us \\ Michael R Frisina \\ Dept. of Animal and Range Sciences, Montana State University \\ PO Box 172900, Bozeman, MT 59717-2900, USA \\ Tel: 1-406-994-7146 E-mail: mike.frisina@montana.edu \\ Joao L Rossi \\ Dept. of Animal and Range Sciences, Montana State University \\ PO Box 172900, Bozeman, MT 59717-2900, USA \\ Tel: 1-406-994-5558_E-mail: joao.rossi@msu.montana.edu
}

Bok Sowell (Corresponding author)

Dept. of Animal and Range Sciences, Montana State University

PO Box 172900, Bozeman, MT 59717-2900, USA

Tel: 1-406-994-5558_E-mail: bok@montana.edu 
MlMacrothink

Received: December 27, 2017

doi:10.5296/emsd.v7i2.12674
Environmental Management and Sustainable Development

ISSN 2164-7682

2018, Vol. 7, No. 2

Accepted: January 12, 2018

URL: https://doi.org/10.5296/emsd.v7i2.12674

\begin{abstract}
Reductions in whitebark pine (Pinus albicaulis) due to blister rust (Cronartium ribicola) and mountain pine beetle (Dendroctonus ponderosae) have prompted some forest managers to consider selective thinning and prescribed fire to reduce competition of whitebark pine with other conifer species. Whitebark pine is an important food source for grizzly bears (Ursus arctos horribilis) in the Greater Yellowstone Ecosystem, but most of the seeds are obtained by raiding red squirrel (Tamiasciurus hudsonicus) middens. Therefore, it is important to understand which attributes maximize red squirrel midden site selection. The objectives of this study were to estimate active midden site selection criteria and quantify the ideal conifer composition associated with red squirrel middens in the Cooke City Basin, MT. Active midden counts were collected in 810,30-meter diameter circular plots, equally spaced along 27 transect lines in the basin. We used generalized linear mixed models to assess variables associated with middens. Midden occurrence probability was positively associated in a curvilinear relationship with conifer canopy cover and the amount of topographic shading. Midden occurrence increased as the percent of whitebark pine increased up to 44 percent. A conifer composition of 44 percent whitebark and 56 percent mixture of subalpine fir (Abies lasiocarpa) and Engelmann spruce (Picea engelmannii) was ideal for midden sites. Whitebark pine treatments to reduce fir and spruce competition should acknowledge the tradeoffs to foraging grizzly bears.
\end{abstract}

Keywords: Whitebark pine zone, Grizzly bear food, Cooke City, MT, Greater Yellowstone Ecosystem

\title{
1. Introduction
}

Throughout the Greater Yellowstone Ecosystem (GYE), whitebark pine (WBP; Pinus albicaulis), a subalpine keystone conifer species (Tomback, Anderies, Carsey, Powell, \& Mellmann-Brown, 2001), has declined. This is primarily due to mountain pine beetle (Dendroctonus ponderosae) infestations and whitebark pine blister rust (Cronartium ribicola) infections, but fire suppression management practices may also be a factor (Logan \& Powell, 2001; Gibson et al., 2008; Logan, Macfarlane, \& Willcox, 2010). Blister rust infections and pine beetle infestations have reduced the number of cone-bearing WBP in excess of 90 percent in some areas (van Manen et al., 2013). It is estimated that mountain pine beetle outbreaks have resulted in WBP mortality in 82 percent of the WBP distribution in the GYE (Macfarlane, Logan, \& Kern, 2013). In the GYE, about 5,686,000 hectares are administered by the U.S. Forest Service and National Park Service. Of this, WBP is found in 1,023,000 hectares (Greater Yellowstone Coordinating Committee Whitebark Pine Subcommittee [GYCCWPS], 2011). Managers are concerned because WBP plays a crucial role in regulating fundamental ecosystem processes (Logan et al., 2010), and its seeds serve as an important seasonal food source for federally protected GYE grizzly bears (Ursus arctos horribilis) 
(Mattson \& Reinhart, 1994).

The GYE grizzly bear was removed from threatened status under the Endangered Species Act in 2017. The grizzly bear population is currently at carrying capacity (Bjornlie et al., 2014, van Manen et al., 2016), but in the past decade, grizzly bears remained a threatened species by federal designation in the GYE due to uncertainty of how this population would cope with potential loss of WBP as a major food source. Findings indicate that grizzly bears are opportunistic omnivores capable of diet-shifting (van Manen et al., 2013). Although federal agencies agreed to delist the GYE grizzly bear, managers still acknowledge the importance of WBP seeds as a primary food source for grizzly bears. Consequently, management priorities still emphasize WBP research and conservation to ensure that WBP seeds are available to bears.

Whitebark pine seeds serve as an important food source for grizzly bears and red squirrels (Mattson \& Reinhart, 1994). Grizzly bears consume WBP seeds as a fall food source (Mattson \& Reinhart, 1994) to build up significant levels of fat crucial for winter survival. Whitebark cones are indehiscent, meaning they do not release seeds when ripe, and remain on the trees. Therefore, WBP seeds are not readily available to grizzly bears, because grizzly bears rarely climb WBP trees to harvest seeds. As a result, grizzly bears depend on red squirrels to harvest WBP cones and store them in midden sites to obtain WBP seeds. It is estimated that over 90 percent of seeds consumed by grizzly bears are obtained by raiding red squirrel middens (Mattson \& Reinhart, 1994).

Active middens are very good indicators of red squirrel habitat selection, because they are located in the center of red squirrel territories (McAdam, Boutin, Sykes, \& Humphries, 2007) and indicate residency (McKinney \& Fiedler, 2010). Therefore, identifying variables associated with midden sites provides the greatest insight regarding red squirrel habitat requirements. Previous studies indicate that total conifer basal area and canopy cover (McKinney \& Fiedler, 2010, Mattson \& Jonkel, 1990; Zugenmeyer \& Koprowski, 2009), slope (Zugenmeyer \& Koprowski, 2009), aspect (Vahle \& Patton, 1983), elevation (Mattson \& Reinhart, 1994) and conifer species compositions (McKinney \& Fiedler, 2010; Koprowski, 2005) are important variables associated with red squirrel midden site selection. Mattson and Reinhart (1990) created a site favorability index for red squirrel midden density and found middens were influenced by the amount of solar radiation. Wood (2007) found more occupied middens in cooler sites with healthy dense trees, which implies selection for darker areas with more shade.

Red squirrels prefer to establish middens in mixed conifer habitats with a diversity of tree species (Mattson \& Reinhart, 1997; McKinney \& Fiedler, 2010; Koprowski, 2005; Mattson \& Reinhart, 1990; Mattson, Kendall, \& Reinhart, 2001). Red squirrel residency in the subalpine zone tends to be low in WBP dominated stands and high in mixed conifer forests comprised primarily of subalpine fir (Abies lasiocarpa) and Engelmann spruce (Picea engelmannii) where WBP comprises less than 50 percent of total conifer species composition (McKinney \& Fiedler, 2010). This suggests that mixed conifer stands in GYE subalpine zones dominated by subalpine fir and Engelmann spruce with interspersed WBP is the most 
suitable habitat for red squirrels, but no studies to our knowledge have attempted to quantify a conifer species composition within mixed conifer forests that provides optimal red squirrel habitat for midden sites. Estimating optimal conifer species mixtures for red squirrel middens in the GYE has important management implications for grizzly bears.

Subalpine zone mixed forests provide good habitat for red squirrels (McKinney \& Fiedler, 2010) but are also key areas of WBP conservation. In light of recent range-wide WBP population declines, managers are developing WBP restoration strategies and initiating programs to enhance WBP stand longevity (GYCCWPS, 2011; Keane \& Parsons, 2010). Treatments include removing competing subalpine fir and Engelmann spruce through mechanical thinning and prescribed fire (GYCCWPS, 2011; Keane \& Parsons, 2010). Although treatment effects are significant, they are relatively localized. Project sites in the northern Rocky Mountains of Montana and Idaho ranged in size from 4 to over 80 hectares (Keane \& Parsons, 2010). These treatments may benefit WBP in the long-term by removing subalpine fir and Engelmann spruce that outcompete WBP but may negatively impact current grizzly bear populations by altering areas most likely to contain red squirrel middens, which supply almost all of the WBP seeds harvested by grizzly bears.

We studied red squirrel habitat selection in the WBP zone of the Cooke City Basin (CCB) of Montana. Research objectives were to estimate forest structure and site characteristic factors (conifer species composition, total canopy cover, slope, and hillshade) that are associated with red squirrel midden site selection, and quantify a conifer species composition at which active middens are most likely to occur. Results of this study will identify areas within mixed conifer forests containing WBP that provide optimal grizzly bear foraging opportunities for WBP seeds.

\section{Materials and Methods}

Field work was conducted in the CCB of Montana in collaboration with the US Forest Service and the US Fish and Wildlife Service. The study area encompassed approximately 91 $\mathrm{km}^{2}$ in the CCB located $6 \mathrm{~km}$ from the northeast entrance of Yellowstone National Park (Mattson, Blanchard, \& Knight, 1992). The area is surrounded by designated wilderness areas and lies within the Yellowstone Grizzly Bear Primary Conservation Area established by the U.S. Fish and Wildlife Service in 1993. Annual average temperature is $1.55 \mathrm{C}$, with average high and low temperatures of $9.1 \mathrm{C}$ and $-6 \mathrm{C}$ respectively. Annual precipitation averages include $6.28 \mathrm{~cm}$ of rainfall and $513 \mathrm{~cm}$ of snowfall (usclimatedata.com, 2017).

A variety of forest communities interspersed with avalanche chutes, talus slopes, alpine meadows, and nonforested openings are located throughout the study area. In the context of this study, the most important aspect of the CCB is that it contains a subalpine zone with one of the largest, healthy, intact WBP populations in the GYE (Macfarlane et al., 2013) and is utilized by grizzly bears despite high levels of human activity (Rossi, 2016). Forest communities are diverse with conifer species compositions including mixtures of WBP, Engelmann spruce, subalpine fir, lodgepole pine (Pinus contorta), and Douglas fir (Pseudotsuga menziesii). The dominant tree species in the subalpine zone include WBP, Engelmann spruce, and subalpine fir. Lodgepole pine and Douglas fir generally occur below 
the subalpine zone. Krumholtz forests of WBP, Engelmann spruce, and subalpine fir are located at the highest elevations at tree line. Mature forests dominated by single conifer species or mixed conifer species are found throughout the area with lodgepole pine and Douglas fir only present at the lowest elevations. The proportion of WBP, Engelmann spruce, subalpine fir, lodgepole pine, and Douglas fir varies among sites in response to a complex of environmental variables.

\subsection{Study Design}

In 1992, the U.S. Forest Service systematically positioned 27 belt transects in 8 drainages in the CCB of Montana. Transects were originally designed to evaluate grizzly bear habitat use and distribution in response to human activity, including mine reclamation and road construction in the CCB. Distance between transects was constant at $500 \mathrm{~m}$ but length varied from $715 \mathrm{~m}$ to $5904 \mathrm{~m}$. Transects were oriented perpendicular to topographic contours to cover elevational gradients which ensured that all forest cover types found throughout the CCB were represented. Transects covered the total elevational range of the study area from $2316 \mathrm{~m}$ to $3078 \mathrm{~m}$ at treeline. Slopes ranging from 0 degrees (flat terrain) to 48 degrees (very steep mountain sides) and north, south, east and west facing aspects were found within transects.

Mixed forests and forests dominated by single conifer species occurred along transects. This allowed for a comparative assessment of the relationship between forest composition and red squirrel habitat selection. The conifer species most abundant in the area were Engelmann spruce, subalpine fir, and WBP. Elevations ranging from 2316 - $2591 \mathrm{~m}$ contained mixed forests composed primarily of subalpine fir and Engelmann spruce that were occasionally interspersed with lodgepole pine and Douglas fir. Whitebark pine was mostly absent from this elevational range but was present above $2591 \mathrm{~m}$ and increased in abundance with elevation, depending on the site. Additionally, 0 to 100 percent mixtures of Engelmann spruce and subalpine fir were present. For analysis, Engelmann spruce and subalpine fir were combined into one conifer group (Pfister, Kovalchik, Arno, \& Presby, 1977), because they were always associated throughout the study area. The variety of conifer species compositions found in the CCB allowed us to estimate an ideal conifer composition for red squirrel midden sites.

Our study was conducted from July to October, 2012, to ensure data were collected when red squirrels were actively caching conifer cones in middens. Red squirrel cone caching activity begins as early as July and is at its peak from mid-August to mid-September (Hutchins \& Lanner, 1982). Circular plots are commonly used to assess squirrel habitat requirements, although plot size varies among studies (Merrick, Bertelsen, \& Koprowski, 2007; Smith \& Mannan, 1994). We used circular plots along the center line of the 27 belt transects designed by the U.S. Forest Service. Each transect line contained 30 evenly spaced $30 \mathrm{~m}$ diameter circular plots resulting in a total of 810 plots with over 18,000 conifers surveyed. Vahle and Patton (1983) indicated that the best red squirrel habitat consists of mixed conifer forests that contain densely grouped conifer stands covering an area of 0.04 hectares (ha) or less. We assessed habitat characteristics within 30 meter diameter plots (total area of 0.071 ha) to ensure that conifer stands within plots were at least 0.04 ha in area. 


\subsection{Field Data}

Data collected in 2012 included tree counts by species, active midden counts, and midden area measurements for each plot. Active middens $(n=201)$ were identified by the presence of freshly cut cones, cone scales, or chewed cone cores on or within larger multiple year accumulations of cone debris (Finley Jr, 1969). Conifers were only included in counts if they were of cone-bearing age ranging from pole trees (Diameter at Breast Height (DBH) of 12.7 $\mathrm{cm}$ to $22.9 \mathrm{~cm}$ ) to mature trees (DBH of $22.9 \mathrm{~cm}$ or larger). Trees smaller than $12.7 \mathrm{~cm} \mathrm{DBH}$ generally did not produce cones (LaMontagne et al., 2013) in the CCB and were therefore not included in our count.

\subsection{GIS Data}

Digital elevation maps (DEM) were used in the software ArcGIS to acquire canopy cover, slope, elevation, aspect, and hillshade values for each $30 \mathrm{~m}$ diameter circular plot $(\mathrm{n}=810)$. Canopy cover was a numerical variable obtained from a $30 \mathrm{~m}$ resolution DEM ArcGIS layer (United States Geological Survey [USGS], 2004) that quantified percent canopy cover in categories. The categories were either 0 percent or 15 to 95 percent by 10 percent increments. Hillshade, which is a measure of the amount of light an area receives based on topography considering azimuth equals $225^{\circ}$ and sun angle equals $45^{\circ}$, was calculated using ArcGIS spatial analyst tools. Lower hillshade values were associated with "cooler" locations (northeast aspects) and lower light conditions, while higher values were associated with "warmer" locations (southwest aspects) and more light exposure. (Ciarniello, Boyce, Heard, \& Seip, 2007).

\subsection{Statistical Analyses}

We used generalized linear mixed models (GLMM) (Zuur, Ieno, Walker, Saveliev, \& Smith, 2009) to assess which measured environmental factors were associated with red squirrel midden site selection in the CCB. The response variable was coded as 1 for plots that contained an active red squirrel midden and 0 for plots where an active midden was absent. This response was assumed to follow binomial (Bernoulli) distribution with the logit link function. Explanatory variables incorporated into the model were percent of WBP, canopy cover, slope, and hillshade for each plot. The conifer species composition variable was identified as the "percent of WBP" to indicate the percent WBP of overall conifer species composition based on tree counts. Conifer species compositions at midden sites were primarily composed of a mixture of WBP, subalpine fir, and Engelmann spruce. Therefore, assessing how conifer species composition impacted midden site selection only required incorporating the percent of WBP contained in a plot. The quadratic term of percent WBP was included in the analysis, because we hypothesized that midden site selection was higher for stands with intermediate percentages of WBP when compared to WBP dominated stands, or stands with no WBP. All variables were included in the model in their original scale, except for hillshade, which was re-scaled from the original $0-255$ interval to the $0-100$ interval to aid model convergence. A random intercept for the categorical variable of transect was included in all models, and variance inflator factors (Zuur et al., 2009) were used to assess collinearity among explanatory variables. We did not include elevation and aspect in 
our models because collinearity was present between elevation and the percent of WBP, and between aspect and hillshade.

Four candidate models were developed using these predictors to test hypotheses associated with red squirrel midden site selection (Table 1). These models were compared using Akaike Information Criterion (AIC), and the model with the lowest AIC was considered the most parsimonious model for red squirrel midden site selection in the CCB. After the model was selected, 85 percent confidence intervals were used to indicate which factors in the model were associated with probability of a red squirrel selecting a midden site. We considered 85 percent confidence intervals to ensure model-selection and parameter-evaluation were consistent (Arnold, 2010). All models were fit using the package "Ime4" (Bates, Mächler, Bolker, \& Walker, 2014) in R software (R Core Team, 2014). The Moran's I test of the R package "ape" (Paradis, Claude, \& Strimmer, 2004) was used to test for spatial autocorrelation in the residuals of the model.

Table 1. Competing models designed to test hypotheses about factors associated with red squirrel midden site selection in the Cooke City Basin, Montana

\begin{tabular}{|c|l|}
\hline Model & \multicolumn{1}{|c|}{ Variables/Tested hypothesis } \\
\hline M0 & $\begin{array}{l}\text { Intercept only } \\
\text { Hypothesis: The measured variables, supported by the literature as good predictors } \\
\text { of high quality red squirrel habitat, are not associated with red squirrel midden site } \\
\text { selection. }\end{array}$ \\
\hline M1 & $\begin{array}{l}\text { Slope + Hillshade + Canopy cover } \\
\text { Hypothesis: Slope, hillshade, and canopy cover are associated with red squirrel } \\
\text { midden site selection in the CCB but the percentage of WBP trees is not associated } \\
\text { with midden site selection. }\end{array}$ \\
\hline M2 & $\begin{array}{l}\text { Slope + Hillshade + Canopy cover + Percent of WBP } \\
\text { Hypothesis: Slope, hillshade, and canopy cover are associated with midden site } \\
\text { selection in the CCB. In addition, the percentage of WB trees is associated with red } \\
\text { squirrel midden site selection in a monotonic way. }\end{array}$ \\
\hline M3 & $\begin{array}{l}\text { Slope + Hillshade + Canopy cover + Percent of WBP + Percent of WBP }{ }^{2} \\
\text { Hypothesis: Slope, hillshade, and canopy cover are associated with midden site } \\
\text { selection in the CCB, and there is a quadratic association between percentage of } \\
\text { WBP trees and probability of midden site selection. }\end{array}$ \\
\hline
\end{tabular}

We used ten-fold cross validation to assess the predictive capability of the model (Boyce, Vernier, Nielsen, \& Schmiegelow, 2002; Johnson, Nielsen, Merrill, McDonald, \& Boyce, 2006) by dividing the data set into ten parts of equal size. The best model was then fit to nine tenths of the data and the remaining tenth was used as a validation set. Ten resource selection probability function (RSPF) bins were created by predicting RSPF values using the fitted coefficients and remaining tenth of the data. Predicted values were grouped using deciles (quantiles from 10 to 100 percent by 10 percent increments). Johnson et al. (2006) advised that bins of equal area should be generated. Since all plots in this study had the same area, organizing data into bins that contained the same number of plots produced bins of equal area. 


\section{Ml Macrothink}

The procedure was repeated using each of the ten parts of the data alternatively as a validation set. Mid-points of the RSPF bins were re-scaled to 0-1 and then regressed against the proportion of used locations in each bin (Johnson et al., 2006). If the models have high predictive capability, the regression of proportion of used locations and RSPF bin mid-points should have high $\mathrm{R}^{2}$, intercept not different than zero, and slope not different than one (Johnson et al., 2006).

\section{Results}

Results from the AIC model selection (Table 2) indicated model 3 (M3) as the most parsimonious among the candidates, which suggested that red squirrel midden site selection in the CCB could be associated with the factors: slope, hillshade, canopy cover, and a quadratic function of the percent of WBP in a plot. Results from the most parsimonious model (M3; Table 3) provided evidence to support an association between probability of midden site selection and all variables included in the model. The odds-ratio of a midden occurring increased about 2 percent per 1 percent increase in canopy cover and decreased about 1.8 percent per 1 percent increase in hillshade. Results of this model also suggested that the probability of red squirrel midden site selection was maximized when WBP comprised 43.6 percent of the overall conifer species composition in plots (Fig 1). Results from the Moran's I test provided no evidence of spatial auto-correlation in the residuals ( $p$-value = $0.69)$.

Even though the estimated correlation between bin mid-points and proportion of used locations in 10-fold cross validation was 0.93 and the $\mathrm{R}^{2}$ of the regression was 0.98 , the confidence intervals for the intercept and coefficient did not contain zero (95\% C.I. $=-0.06$, $-0.01)$ and one $(95 \%$ C.I. $=1.25,1.57)$ respectively (Fig 2$).$ When the regression was repeated excluding the bins associated with locations of the 20 percent highest probability of use (points A and B of Fig 2) the intercept and coefficient were not different than zero (95\% C.I. $=-0.03,0.01)$ and one $(95 \%$ C.I. $=0.33,1.07)$ respectively. These results indicated that the model was good at predicting red squirrel midden site selection in areas of 80 percent lowest use, but it overestimated the probability of selection in areas of 20 percent highest use. The conditional modes of the random effects for transects (Fig 3) indicated there was relatively high variability in probability of use for the different transects, mainly for transects ML1 and ML2. The odds of selecting a midden site was 32 times higher in ML1 and 7.6 times higher in ML2 than the estimated average (Fig 3). These results indicate that there could be factors associated with transects that were not accounted for in our analysis such as age of stand or tree density. 


\section{Macrothink}

Environmental Management and Sustainable Development

ISSN 2164-7682

2018, Vol. 7, No. 2

Table 2. Results from the Akaike Information Criterion (AIC) model selection of red squirrel midden site selection candidate models with models ranked from the most parsimonious (M3) to the least parsimonious (M0)

\begin{tabular}{|l|l|l|l|l|}
\hline Model & $\begin{array}{l}\text { Degrees of } \\
\text { freedom }\end{array}$ & AIC & $\begin{array}{l}\text { delta } \\
\text { AIC }\end{array}$ & $\begin{array}{l}\text { AIC } \\
\text { Weight }\end{array}$ \\
\hline $\begin{array}{l}\text { M3 = Slope + Hillshade + Canopy cover + } \\
\text { Percent of WBP + Percent of WBP }\end{array}$ & 7 & 497.59 & 0.00 & 0.86 \\
\hline M1 = Slope + Hillshade + Canopy cover & 5 & 501.90 & 4.32 & 0.10 \\
\hline $\begin{array}{l}\text { M2 = Slope + Hillshade + Canopy cover + } \\
\text { Percent of WBP }\end{array}$ & 6 & 503.81 & 6.23 & 0.04 \\
\hline M0 = Intercept only & 2 & 519.10 & 21.51 & 0.00 \\
\hline
\end{tabular}

Table 3. Parameter estimates, standard (Std.) error, exponentiated (Exp.) estimates and confidence intervals (C.I.) for exponentiated estimates from the most parsimonious model (M3) for red squirrel midden site selection in the Cooke City Basin, Montana

\begin{tabular}{|l|l|l|l|l|l|}
\hline Variable & Estimate & Std. Error & Exp. Estimate & Exp. C.I. Lower & Exp. C.I. Upper \\
\hline (Intercept) & -2.3136 & 0.808 & 0.0989 & 0.0309 & 0.3166 \\
\hline Percent WBP & 0.0416 & 0.015 & 1.0425 & 1.0197 & 1.0659 \\
\hline Percent BP & $-0.4772 * *$ & $0.175^{* *}$ & 0.9995 & 0.9992 & 0.9998 \\
\hline Slope & -0.0216 & 0.018 & $0.979 *$ & 0.9540 & 1.0038 \\
\hline Hillshade & -0.0178 & 0.009 & $0.9824 *$ & 0.9700 & 0.9949 \\
\hline Canopy cover & 0.0196 & 0.005 & $1.0198^{*}$ & 1.0121 & 1.0275 \\
\hline
\end{tabular}

* Exponentiated coefficients of these variables can be interpreted as the multiplicative effect for one-unit change in the explanatory variable on the odds-ratio of midden site selection. The exponentiated estimate suggests that the odds of site selection increased $2 \%$ for an increase of $1 \%$ in canopy cover and decreased $2.1 \%$ and $1.8 \%$ for a $1 \%$ unit increase in slope and hillshade, respectively. An exponentiated confidence interval that overlaps 1 indicates no selection of avoidance associated with the predictor. Interpretation of percent WBP, which includes the quadratic term, requires the use of a plot (Figure 1).

**Coeffiecient and standard error of the quadratic term were multiplied by $10^{3}$ to allow visualization of more decimals places. 

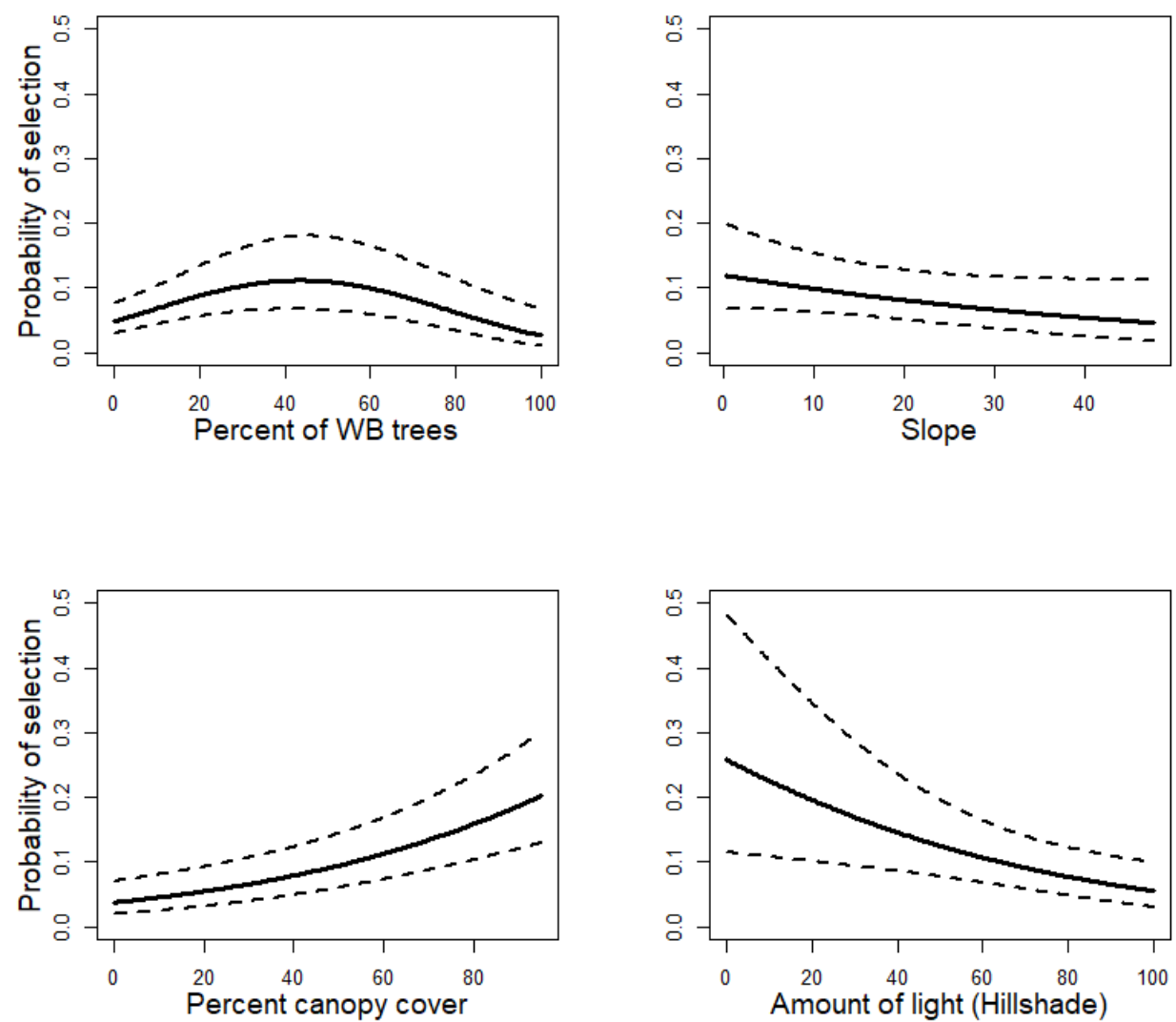

Figure 1. Estimated effects of habitat variables ( $85 \%$ confidence bands) on red squirrel midden site selection

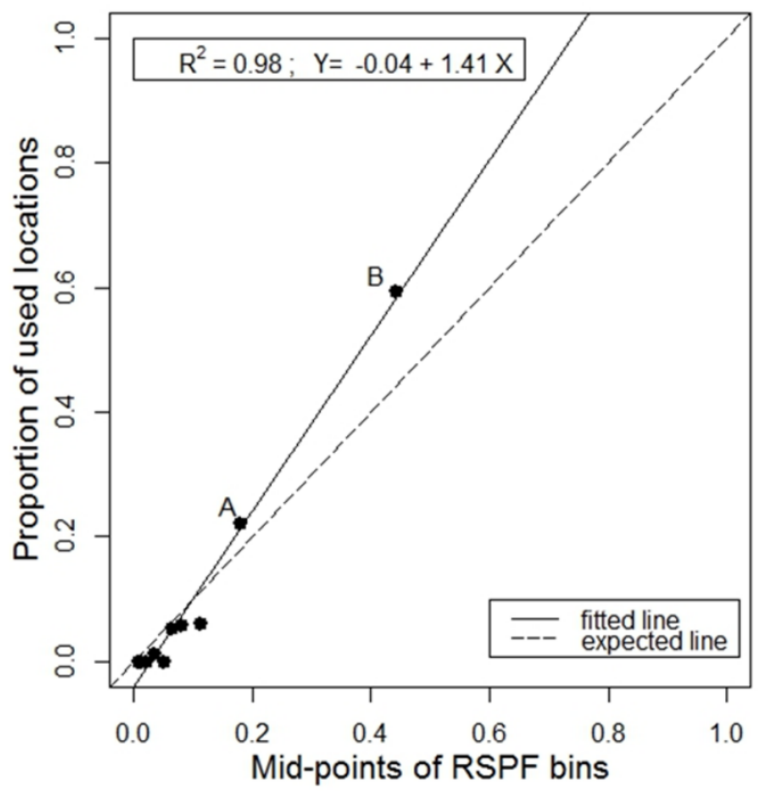

Figure 2. Mid-points of RSPF bins plotted against proportion of used locations. Models with high predictive capability yield regression lines with intercept not different than zero and coefficient not different than one (expected line). The fitted regression line indicates good prediction for the areas of lowest $80 \%$ use (excluding points A and B) 


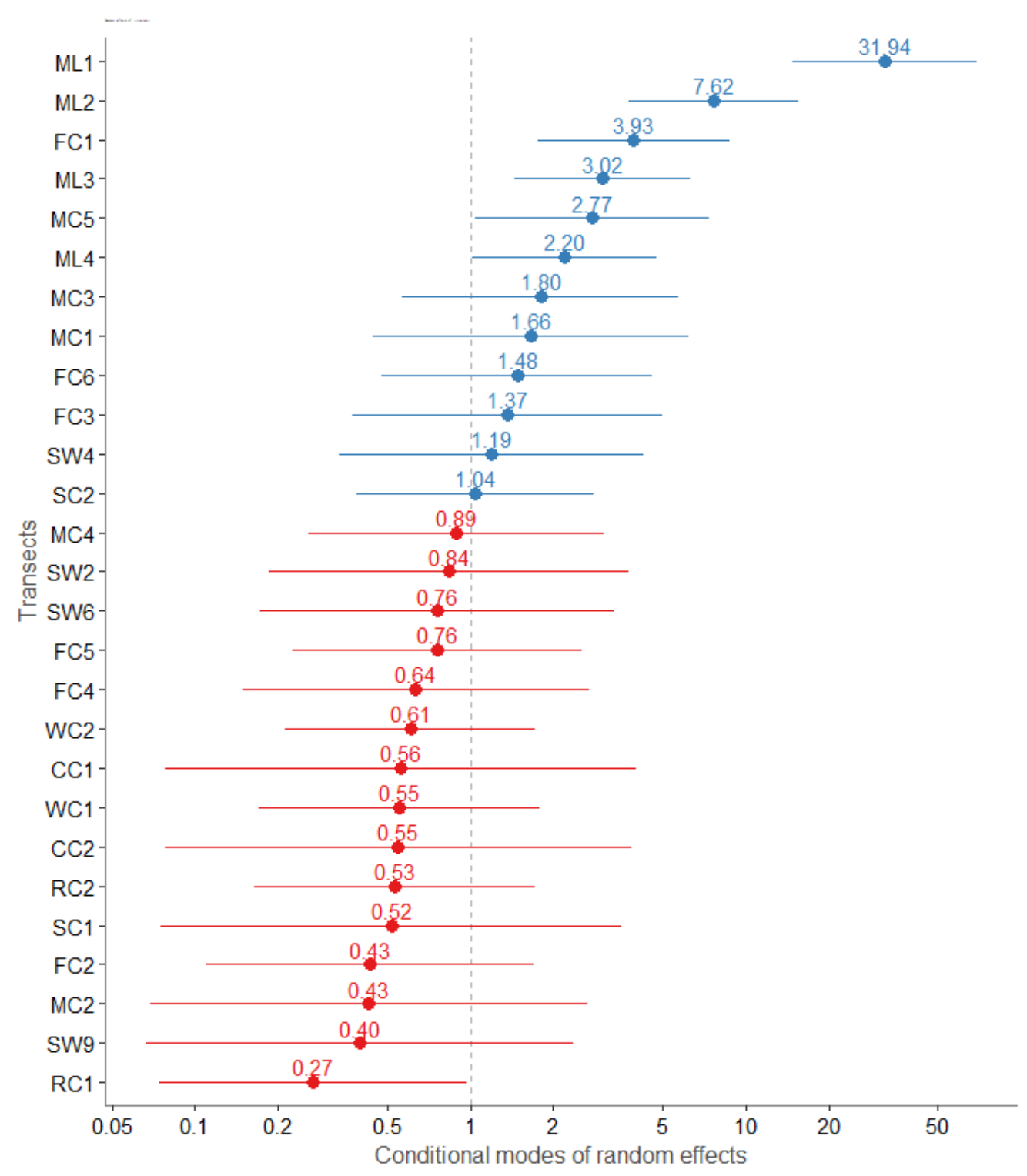

Figure 3. Exponentiated conditional modes (95\% confidence bands) estimated for transects regarding red squirrel midden site selection

The estimated values can be interpreted as the multiplicative effect on odds-ratios of red squirrel midden site selection. For example, the estimate of 1.66 for the transect MC1 suggests that the odds of a location having an active red squirrel midden site in MC1 was 66\% higher than the average.

\section{Discussion}

Active middens are located in the center of red squirrel territories (McAdam et al., 2007; Gurnell, 1984) and indicate residency (McKinney \& Fiedler, 2010). Therefore, they are very good indicators of red squirrel habitat selection, and conclusions about red squirrel habitat selection can be made by assessing forest structure and site-specific variables associated with active midden sites. 
Results of our study supported the hypothesis that red squirrels select habitats to establish middens based on the amount of hillshade, canopy cover, and WBP present in a conifer stand. The probability of an active midden site occurring increased as canopy cover increased but decreased as hillshade values increased, which suggests that red squirrels selected cool, shaded areas with dense canopy cover. These sites may help preserve cones stored within middens, provide greater protection from predators, and provide a more abundant and consistent conifer seed food source. The increased probability of an active midden occurring at a site as shade increased is supported by the findings of Finley Jr. (1969) who reported that middens require cool, moist conditions to keep stored cones from drying out, opening, and losing seeds. Previous studies also indicated that midden occurrence increased as canopy cover increased (McKinney \& Fiedler, 2010; Mattson \& Jonkel, 1990; Zugenmeyer \& Koprowski, 2009) confirming the findings from our study.

Midden occurrence probability was highly variable among transects, which indicates that other factors not accounted for in our analysis may be responsible for the observed variations. While other factors may be at play, we suggest that variations observed may be due to the fact that middens did not always occur in plots along transects that the model predicted should contain middens. The explanation could be attributed to our sampling strategy. Our transects were oriented perpendicular to topographic contours to cover elevational gradients. This ensured that all forest compositions found throughout the CCB were represented among the $810,30 \mathrm{~m}$ diameter circular plots contained within transects, but we were restricted to surveying for middens in areas only contained within plots. Even though some plots that the model predicted should have middens were devoid of middens, it is possible that middens were present in adjacent areas surrounding our plots but were not accounted for in our study.

Furthermore, mixed conifer habitats with a diversity of conifer species have been identified as red squirrel preferred habitat (Mattson \& Reinhart, 1997; McKinney \& Fiedler, 2010; Koprowski, 2005; Mattson \& Reinhart, 1990; Mattson et al., 2001). Our results similarly indicated that red squirrels preferentially selected habitats in mixed conifer forests to establish middens, and midden occurrence was maximized in mixed forests comprised of approximately 44 percent WBP and a 56 percent mixture of subalpine fir and Engelmann spruce. We identified a quadratic relationship between midden occurrence and the percent WBP of overall conifer species composition in our plots. Probability of a midden occurring increased as the percent WBP in overall composition increased up to 44 percent but decreased after this threshold was surpassed.

These findings indicated that red squirrel habitat conditions became less hospitable as WBP abundance in stands increased above 44 percent. Similar conclusions were made by McKinney and Fiedler (2010) who observed that red squirrel population residency was low in WBP-dominated stands (WBP comprises greater than 50 percent of total conifer species basal area) and high in mixed conifer forests with WBP comprising less than 50 percent of total conifer species basal area. Mattson and Reinhart (1997) also concluded that red squirrels prefer mixed conifer habitats but indicated that midden occurrence was positively associated with lodgepole pine basal area. Our results differed from Mattson and Reinhart (1997) due to differences in subalpine zone conifer species compositions between our study areas. 
Lodgepole pine was most commonly associated with WBP at midden locations in the Mount Washburn study area of Mattson and Reinhart (1997), but lodgepole only occurred in 5 percent of our plots that contained middens in the CCB. The remaining 95 percent of our plots with middens were located in mixed forests comprised only of subalpine fir, Engelmann spruce, and WBP.

Differences in habitat conditions between $\mathrm{CCB}$ mixed forests containing WBP and WBP-dominated forests provide one possible explanation for the observed decrease in midden occurrence as WBP abundance increased above 44 percent in conifer stands. Whitebark is stress-tolerant and dominates the upper subalpine zone at elevations ranging from $2743 \mathrm{~m}-2896 \mathrm{~m}$ at treeline where harsh conditions inhibit the growth of less tolerant, competing conifer species (Arno, 2001). As wind exposure and elevation increase, WBP dominance increases (Mattson \& Reinhart, 1994). Mature WBP stands grow in clumps and are widely disconnected, which greatly increases exposure to prevailing winds and provides less overhead protection for red squirrels. Alternatively, mixed forests containing WBP are located in the lower subalpine zone $(2591 \mathrm{~m}-2743 \mathrm{~m})$ where conditions are not as harsh, enabling subalpine fir and Engelmann spruce to persist with WBP (Arno, 2001). Forests in this area are dense and highly connected (Pfister et al., 1977) providing red squirrels with greater protection from wind and overhead predators. As a result, middens were more likely to occur in mixed conifer forests containing WBP rather than WBP-dominant forests in our study area. Our findings were supported by those of Mattson and Reinhart (1994) which indicated that a negative relationship exists between WBP dominance and red squirrel density.

Additionally, differences in seed energy content among conifer species and the inconsistency of WBP annual cone crops may also explain why midden sites were primarily found in mixed forests containing WBP, subalpine fir, and Engelmann spruce. Red squirrels are strategic foragers and harvest cones from conifer species with the highest cone energy content first (Smith, 1968; Smith, 1970). In the GYE, WBP seeds have the highest energy content (27.7 kcal per cone) (Smith, 1970; Tomback, 1982) of all conifer species present: subalpine fir, Engelmann spruce, lodgepole pine, and Douglas fir (Smith, 1970; Tomback, 1982). Subalpine fir yields the second highest cone energy content at $15.7 \mathrm{kcal}$ per cone (Smith, 1970; Tomback, 1982) which is roughly half that of WBP. We observed an increase in midden occurrence as WBP abundance increased to 44 percent of overall composition in conifer stands, which suggests that red squirrels prefer to consume WBP seeds when available.

The decrease in midden occurrence as WBP increased above 44 percent may be explained by inconsistency of WBP annual cone crops. Whitebark is a masting species and has variable annual yields of seed production with good and poor seed production alternating every two to three years (Costello et al., 2014). Subalpine fir and Engelmann spruce may have more consistent annual cone crops than WBP (Boe, 1954), thus providing red squirrels with a more stable food supply. In our study area, red squirrels maximized survival by establishing middens in mixed forests containing a slightly larger abundance of subalpine fir and Engelmann spruce than WBP to ensure that they would still have an adequate cone supply to survive winter even in years of WBP cone crop failure. Mixed forests provide more stable 
and predictable annual seed supplies for red squirrels, because multiple conifer species are present. It is unlikely that all species in mixed forests will experience poor cone crops or cone crop failures in a given year, which ensures that red squirrels have dependable annual seed supplies.

Podruzny, Reinhart and Mattson (1997) examined the effects of the 1988 Yellowstone fires on red squirrel middens and bear use of middens in the Mount Washburn region of Yellowstone National Park. They found that bear use of pine seeds decreased 64\% from pre-fire to post fire. They predicted fires would negatively impact red squirrels and bears for 70 to 100 years. Podruzny et al. (1997) suggested that managers should maintain large secure areas with habitat that supports stable WBP and red squirrel numbers and re-evaluate prescribed fires or timber harvest that result in further loss of seed producing conifers. Managers are currently targeting subalpine mixed conifer forests containing WBP for thinning and burning to prevent successional replacement of WBP by Engelmann spruce and subalpine fir, and to prevent the spread of mountain pine beetle (GYCCWPS, 2011). However, mountain pine beetles are found in $95 \%$ of GYE forest stands containing WBP (Macfarlane, Logan \& Kern, 2009) and have caused moderate to severe mortality in $82 \%$ of the WBP distribution in the GYE (Macfarlane et al. 2013). A potential solution for this loss is to plant WBP seeds in openings created by thinning or burning management. These solutions offer long-term responses to reduce WBP losses in the next 300 years, but sacrifice WBP seed production in the short-term.

\section{Conclusion}

Red squirrels are critical intermediary agents that make whitebark pine seeds available to grizzly bears by storing whitebark pine cones in middens. Successful management of whitebark pine for the current grizzly bear population relies on understanding which areas within mixed conifer forests are most likely to contain red squirrel middens. Our study found that red squirrel midden sites are most likely located in mixed forest conifer stands comprised of approximately 44 percent whitebark pine and 56 percent subalpine fir and Engelmann spruce. Our findings inform multi-resource management decisions affecting areas with similar conifer species composition in the Greater Yellowstone Ecosystem subalpine zone by identifying optimal grizzly bear foraging areas.

Whitebark pine treatments to reduce fir and spruce competition should acknowledge the tradeoff to foraging grizzly bears. Although removing shade-tolerant conifers through prescribed burning or selective cutting is a means of promoting whitebark pine growth by reducing competition, decades are required for seedlings and saplings to become cone-bearing trees that benefit squirrels and bears. Moreover, forests with whitebark pine are vulnerable to natural fire events. Given the frequency and size of wildfires in the Greater Yellowstone Ecosystem, natural processes will inevitably reduce the current amount of ideal squirrel habitat in the subalpine zone, which reinforces the need to consider the effects of small-scale prescribed treatments. Therefore, management objectives for subalpine forests with high midden density should be carefully considered. 


\section{Acknowledgement}

We thank all of the field technicians who helped perform the field work and data collection necessary to complete this study. Funding for this project was provided by the US Forest Service, US Fish and Wildlife Service, Montana State University Agricultural Experiment Station, Dick and Mary Ohman, Gerry Bennet and the Hormay Foundation.

\section{References}

Arno, S. F. (2001). Community types and natural disturbance processes. Whitebark pine communities: ecology and restoration. Edited by DF Tomback, SF Arno, and RE Keane. Island Press, Washington, DC, 74-88.

Arnold, T. W. (2010). Uninformative parameters and model selection using Akaike's Information Criterion. Journal of Wildlife Management, 74(6), 1175-1178. https://doi.org/10.1111/j.1937-2817.2010.tb01236.x

Bates, D., Mächler, M., Bolker, B., \& Walker, S. (2014). Fitting linear mixed-effects models using lme4. arXiv preprint arXiv:1406.5823.

Bjornlie, D. D., Thompson, D. J., Haroldson, M. A., Schwartz, C. C., Gunther, K. A., Cain, S. L., ... Aber, B. C. (2014). Methods to estimate distribution and range extent of grizzly bears in the Greater Yellowstone Ecosystem. Wildlife Society Bulletin, 38(1), 182-187.

https://doi.org/10.1002/wsb.368

Boe, K. N. (1954). Periodicity of cone crops for five Montana conifers. In Proceedings of the Montana Academy of Sciences, 14, 5-9.

Boyce, M. S., Vernier, P. R., Nielsen, S. E., \& Schmiegelow, F. K. (2002). Evaluating resource selection functions. Ecological modelling, 157(2), 281-300.

https://doi.org/10.1016/S0304-3800(02)00200-4

Ciarniello, L. M., Boyce, M. S., Heard, D. C., \& Seip, D. R. (2007). Components of grizzly bear habitat selection: density, habitats, roads, and mortality risk. Journal of Wildlife Management, 71(5), 1446-1457. https://doi.org/10.2193/2006-229

Costello, C. M., Manen, F. T., Haroldson, M. A., Ebinger, M. R., Cain, S. L., Gunther, K. A., \& Bjornlie, D. D. (2014). Influence of whitebark pine decline on fall habitat use and movements of grizzly bears in the Greater Yellowstone Ecosystem. Ecology and evolution, 4(10), 2004-2018. https://doi.org/10.1002/ece3.1082

Finley Jr., R. B. (1969). Cone caches and middens of Tamiasciurus in the Rocky Mountain region. Miscellaneous Publications, Museum of Natural History, University of Kansas, 51, 233-273.

Gibson, K. E., Skov, K., Kegley, S., Jorgensen, C., Smith, S., \& Witcosky, J. (2008). Mountain pine beetle impacts in high-elevation five-needle pines: current trends and challenges. US Department of Agriculture, Forest Service, Forest Health Protection Washington, DC, USA.

Greater Yellowstone Coordinating Committee Whitebark Pine Subcommittee. (2011) 
Whitebark Pine Strategy for the Greater Yellowstone Area. 41 p.

Gurnell, J. (1984). Home range, territoriality, caching behaviour and food supply of the red squirrel (Tamiasciurus hudsonicus fremonti) in a subalpine lodgepole pine forest. Animal Behaviour, 32(4), 1119-1131. https://doi.org/10.1016/S0003-3472(84)80228-6

Hutchins, H. E., \& Lanner, R. M. (1982). The central role of Clark's nutcracker in the dispersal and establishment of whitebark pine. Oecologia, 55(2), 192-201.

https://doi.org/10.1007/BF00384487

Johnson, C. J., Nielsen, S. E., Merrill, E. H., McDonald, T. L., \& Boyce, M. S. (2006). Resource selection functions based on use-availability data: theoretical motivation and evaluation methods. Journal of wildlife Management, 70(2), 347-357.

https://doi.org/10.2193/0022-541X(2006)70[347:RSFBOU]2.0.CO;2

Keane, R. E. \& Parsons, R. A. (2010) Management guide to ecosystem restoration treatments: whitebark pine forests of the northern Rocky Mountains. Fort Collins (CO): USDA Forest Service, U.S. Rocky Mountain Research Station; 2010 Jan. Report No.: RMRS-GTR-232. https://doi.org/10.2737/RMRS-GTR-232

Koprowski, J. L. (2005). The response of tree squirrels to fragmentation: a review and synthesis. In Animal Conservation forum (Vol. 8, No. 4, pp. 369-376). Cambridge University Press. https://doi.org/10.1017/S1367943005002416

LaMontagne, J. M., Williams, C. T., Donald, J. L., Humphries, M. M., McAdam, A. G., \& Boutin, S. (2013). Linking intraspecific variation in territory size, cone supply, and survival of North American red squirrels. Journal of Mammalogy, 94(5), 1048-1058.

https://doi.org/10.1644/12-MAMM-A-245.1

Logan, J. A., \& Powell, J. A. (2001). Ghost forests, global warming, and the mountain pine beetle (Coleoptra: Scolytidae). American Journal of Entomology. 47(3), 160-172.

https://doi.org/10.1093/ae/47.3.160

Logan, J. A., Macfarlane, W. W., \& Willcox, L. (2010) Whitebark pine vulnerability to climate-driven mountain pine beetle disturbance in the Greater Yellowstone Ecosystem. Ecological Applications, 20, 895-902. https://doi.org/10.1890/09-0655.1

Macfarlane, W. W., Logan, J. A., \& Kern, W. R. (2009). Using the landscape assessment system (LAS) to assess mountain pine beetle-caused mortality of whitebark pine, Greater Yellowstone Ecosystem, 2009. Project report prepared for the Greater Yellowstone Coordinating Committee, Whitebark Pine Subcommittee, Jackson, Wyoming. 69p.

Macfarlane, W. W., Logan, J. A., \& Kern, W. R. (2013). An innovative aerial assessment of Greater Yellowstone Ecosystem mountain pine beetle-caused whitebark pine mortality. Ecological Applications, 23, 421-437. https://doi.org/10.1890/11-1982.1

Mattson, D. J., \& Jonkel, C. (1990). Stone pines and bears. In: Schmidt, W. C., McDonald, K. J., editors. Proceedings of a symposium on whitebark pine ecosystems: ecology and management of a high mountain resource; 1989 Mar 29-31; Bozeman, MT. Ogden, UT: 
USDA Forest Service, Intermountain Research Station, 223-226.

Mattson, D. J., \& Reinhart, D. E. (1994) Bear use of whitebark pine seeds in North America. In: Schmidt, W. C., \& Holtmeier, F. K. editors. Proceedings - International Workshop on Subalpine Stone Pines and Their Environments: the Status of Our Knowledge; 1992 Sep 5-11; St. Moritz, Switzerland. Ogden, UT: USDA Forest Service, Intermountain Research Station, 212-220.

Mattson, D. J., \& Reinhart, D. P. (1990) Whitebark pine on the Mount Washburn massif, Yellowstone National Park. In: Schmidt, W. C., McDonald, K. J., editors. Proceedings of a symposium on whitebark pine ecosystems: ecology and management of a high mountain resource; 1989 Mar 29-31; Bozeman, MT. Ogden, UT: USDA Forest Service, Intermountain Research Station, 106-117.

Mattson, D. J., \& Reinhart, D. P. (1997). Excavation of red squirrel middens by grizzly bears in the whitebark pine zone. Journal of Applied Ecology, 926-940.

https://doi.org/10.2307/2405283

Mattson, D. J., Blanchard, B. M., \& Knight, R. R. (1992). Yellowstone grizzly bear mortality, human habituation, and whitebark pine seed crops. The Journal of Wildlife Management, 432-442. https://doi.org/10.2307/3808855

Mattson, D. J., Kendall, K. C., \& Reinhart, D. P. (2001). Whitebark pine, grizzly bears and red squirrels. In: Tomback, D. F., Arno, S. F., Keane, R. E., editors. Whitebark pine communities: ecology and restoration. Washington, DC: Island Press, 121-136.

McAdam, A. G., Boutin, S., Sykes, A. K., \& Humphries, M. M. (2007). Life histories of female red squirrels and their contributions to population growth and lifetime fitness. Ecoscience, 14(3), 362-369.

https://doi.org/10.2980/1195-6860(2007)14[362:LHOFRS]2.0.CO;2

McKinney, S. T., \& Fiedler, C. E. (2010). Tree squirrel habitat selection and predispersal seed predation in a declining subalpine conifer. Oecologia, 162(3), 697-707.

https://doi.org/10.1007/s00442-009-1496-5

Merrick, M. J., Bertelsen, S. R., \& Koprowski, J. L. (2007). Characteristics of Mount Graham red squirrel nest sites in a mixed conifer forest. Journal of Wildlife Management, 71(6), 1958-1963. https://doi.org/10.2193/2006-260

Paradis, E., Claude, J., \& Strimmer, K. (2004). APE: analyses of phylogenetics and evolution in R language. Bioinformatics, 20(2), 289-290. https://doi.org/10.1093/bioinformatics/btg412

Pfister, R. D., Kovalchik, B. L., Arno, S. F., \& Presby, R. C. (1977). Forest habitat types of Montana. Ogden (UT): USDA Forest Service, U.S. Intermountain Forest and Range Experiment Station; June Report No.: INT-GTR-34.

Podruzny, S. R., Reinhart, D. P., \& Mattson, D. J. (1997). Fire, red squirrels, whitebark pine, and Yellowstone grizzly bears. Ursus, 11, 131-138. 


\section{Mll Macrothink}

Environmental Management and Sustainable Development

ISSN 2164-7682

2018, Vol. 7, No. 2

R Core Team. (2014). R: A language and environment for statistical computing. R Foundation for Statistical Computing.

Rossi, J. L. (2016). The influence of mine reclamation and highway reconstruction activities on grizzly bear habitat selection in the Cooke City Basin, Montana (Doctoral dissertation, Montana State University-Bozeman, College of Agriculture).

Smith, A. A., \& Mannan, R. W. (1994). Distinguishing characteristics of Mount Graham red squirrel midden sites. The Journal of wildlife management, 437-445.

https://doi.org/10.2307/3809314

Smith, C. C. (1968). The adaptive nature of social organization in the genus of three squirrels Tamiasciurus. Ecological Monographs, 38(1), 31-64. https://doi.org/10.2307/1948536

Smith, C. C. (1970). The coevolution of pine squirrels (Tamiasciurus) and conifers. Ecological Monographs, 40(3), 349-371. https://doi.org/10.2307/1942287

Tomback, D. F. (1982). Dispersal of whitebark pine seeds by Clark's nutcracker: a mutualism hypothesis. The Journal of Animal Ecology, 451-467. https://doi.org/10.2307/3976

Tomback, D. F., Anderies, A. J., Carsey, K. S., Powell, M. L., \& Mellmann-Brown, S. (2001), Delayed seed germination in whitebark pine and regeneration patterns following the Yellowstone fires. Ecology, 82, 2587-2600.

https://doi.org/10.1890/0012-9658(2001)082[2587:DSGIWP]2.0.CO;2

United States Geological Survey [USGS] Landfire Data Distribution Site [Internet]. Cooke City (MT): Landfire. c2004 - [cited 2017 May 8]. Available from:

http://landfire.cr.usgs.gov/viewer.

usclimatedata.com [Internet]. Cooke City (MT): U.S. climate data; c2017 [cited 2017 May 8]. Available from:

http://www.usclimatedata.com/climate/cooke-city/montana/united-states/usmt0076.

Vahle, J. R., \& Patton, D. R. (1983). Red squirrel cover requirements in Arizona mixed conifer forests. Journal of Forestry, 81(1), 14-22.

van Manen, F. R., Haroldson, M. A., Frances, M. M., Irvine, K. M., Kristin, L., Daniel, T., ... Interagency Grizzly Bear Study Team. (2013). Response of Yellowstone grizzly bears to changes in food resources: A synthesis. Final report to the Interagency Grizzly Bear Committee and Yellowstone Ecosystem Subcommittee (pp. 1-58). US Geological Survey,

van Manen, F. T., Haroldson, M. A., Bjornlie, D. D., Ebinger, M. R., Thompson, D. J., Costello, C. M., \& White, G. C. (2016). Density dependence, whitebark pine, and vital rates of grizzly bears. Journal of Wildlife Management, 80(2), 300-313.

https://doi.org/10.1002/jwmg.1005

Wood, D. J. A., Drake, S, Rushton, S. P, Rautenkranz, D., Lurz, P. W. W., \& Koprowski, J. L. (2007). Fine-Scale Analysis of Mount Graham Red Squirrel Habitat Following Disturbance. Journal of Wildlife Management, 71(7), 2357-2364. https://doi.org/10.2193/2006-511 


\section{Macrothink}

Zugenmeyer, C. A., \& Koprowski, J. L. (2009) Habitat selection is unaltered after severe insect infestation: concerns for forest-dependent species. Journal of Mammalogy. 90(1):175182. https://doi.org/10.1644/07-MAMM-A-399.1

Zuur, A. F., Ieno, E. N., Walker, N. J., Saveliev, A. A., \& Smith, G. M. (2009). Mixed effects models and extensions in ecology with R. Gail M, Krickeberg K, Samet J.M., Tsiatis A., Wong W., editors. New York, NY: Spring Science and Business Media.

https://doi.org/10.1007/978-0-387-87458-6

\section{Copyright Disclaimer}

Copyright for this article is retained by the author(s), with first publication rights granted to the journal.

This is an open-access article distributed under the terms and conditions of the Creative Commons Attribution license (http://creativecommons.org/licenses/by/3.0/). 